\title{
Case reports of amniotic membrane derived-cell treatment for feline chronic renal failure
}

\author{
Seul Ah $\mathrm{Noh}^{1,2}$, Taeho Kim ${ }^{1,2}$ and Junguk $\mathrm{Ju}^{1,2, *}$ \\ ${ }^{1}$ AniCom Therapeutics Inc., Seoul 04599, Korea \\ ${ }^{2}$ AniCom Medical Center, Animal Hospital, Seoul 04599, Korea
}

Received May 13, 2021

Revised June 14, 2021

Accepted June 15, 2021

\section{*Correspondence}

Junguk Ju

E-mail: fire0809@hanmail.net

\section{ORCID}

https://orcid.org/0000-0002-9442-1548

\begin{abstract}
Three different cats who had chronic kidney disease (CKD) were treated for more than one month with fluid therapy in an animal clinic. Although this long-term treatment and hospitalization, there was no clinical improvement in clinical signs as well as serum biochemical indexes including blood urea nitrogen (BUN), creatinine (CREA), and phosphate (PHOS). All cases were then injected three times with allogeneic stem cells through an intravenous route for treatment on Day 0,7 , and 14 or 30 . On the same day, clinical observation and blood tests for serum biochemistry were conducted together. Upon administrating stem cells to the CKD cats, clinical conditions and the indexes of BUN and CREA were clinically improved within normal ranges. Additionally, one of the cats who had the renal cysts presented clinical improvement with showing decreased cysts size than before.
\end{abstract}

Keywords: chronic kidney disease, feline, stem cells

\section{INTRODUCTION}

Chronic kidney disease (CKD) is the most common kidney disease in cats. CKD is characterized by structural and/or functional abnormalities of one side or both sides of the kidneys, resulting in subsequent progressive loss of renal function. The clinical signs of CKD are polyuria and polydipsia (PU/PD), anorexia, vomiting, diarrhea, depression, and weight loss (Polzin, 2017). The classic treatment for CKD includes conservative medical management, dietary therapy, and renal replacement therapy. The goal of treatment is to improve the rate of progression, stabilize body condition, and maintain the patient with a good quality of life (Chan et al., 2014).

Currently, available therapy cannot halt kidney damage and improve renal function in cats with CKD. In recent studies, stem cells have been suggested as a new effec- tive treatment option for managing CKD. Mesenchymal stem cells exert therapeutic potential mediated by various processes, such as immunomodulatory actions and the capacity to increase cellular repair (Quimby et al., 2011).

Mesenchymal stem cells are isolated from various tissues such as adipose tissue, bone marrow, dental pulp, and placenta, and clinical studies on regenerative medicine and the clinical case of stem cell therapy are being actively conducted (Vidane et al., 2014; Moon et al., 2018; Lee et al., 2019a). However, in the case of skin, adipose tissue, and dental pulp, an invasive method is required, so there is a limit to using it as a resource for stem cell therapy in animal clinics (Webb et al., 2012; Lee et al., 2019b). Mesenchymal stem cells isolated from the amniotic membrane have similar stemness to other mesenchymal stem cells and have advantages such as a non-invasive method, and easy to obtain large amounts of cells (De Coppi et al., 
2007; Filioli Uranio et al., 2011; Mahiddine et al., 2020).

According to the US National Institutes of Health database (ClinicalTrials.gov), as of 2016, there were more than 600 clinical studies of human chronic renal failure using mesenchymal stem cells worldwide in 2016. In addition, many preclinical studies were progressed in chronic kidney disease to improve kidney function and repair, and creatinine and BUN, which are major hematological levels of renal failure, improved after stem cell treatment (Cetinkaya et al., 2019; Jo et al., 2019).

In this report, we describe the therapeutic effects of mesenchymal stem cells from the amniotic membrane in cats with CKD.

\section{CLINICAL CASE}

First case, a 13-year-old spayed female Persian cat (Case 1), was $2.5 \mathrm{~kg}$ and diagnosed CKD with azotemia (Blood Urea Nitrogen, BUN; 112 mg/dL creatinine, CREA; 5.28 $\mathrm{mg} / \mathrm{dL}$ ) and hyperphosphatemia (phosphorus, PHOS; $10.2 \mathrm{mg} / \mathrm{dL}$ ). A 15-year-old female Korean domestic cat (Case 2) was $4.1 \mathrm{~kg}$ and diagnosed and found azotemia (BUN; $66.4 \mathrm{mg} / \mathrm{dL}, \mathrm{CREA} ; 5.5 \mathrm{mg} / \mathrm{dL}$ ) and hypophospha- temia (PHOS; $2.2 \mathrm{mg} / \mathrm{dL}$ ) in laboratory tests. A 8-yearold spayed female British Short Hair cat with CKD(Case 3) weighed $4 \mathrm{~kg}$ and was also high levels of CKD-related indicators BUN (140 mg/dL), CREA (10.58 mg/dL) and PHOS $(11.4 \mathrm{mg} / \mathrm{dL})$. There were no clinicl improvement although continuous fluid therapy and hospitalization before the stem cell injection. Actually the all patients showed anorexia, depression, vomiting and dehydration. (Table 1).

In Case 1, abdominal ultrasonography revealed several round anechoic cysts throughout the renal parenchyma, loss of renal corticomedullary junction and a $41 \times 28 \mathrm{~mm}$ sized, well-demarcated, round-shaped anechoic structure with distal acoustic enhancement in the left kidney (Fig. 1A). According to the staging system of the International Renal Interest Society (IRIS), this patient was made as IRIS stage 4 CKD. After a definite diagnosis was made, the cat received supportive care with conservative medical management, fluid therapy, and dietary therapy.

All cats were treated at the Anicom Medical Center (Seoul, Korea) for stem cell therapy. Physical examination and serum biochemistry were performed on day $0,7,14$ and 30. Biomarker indexes in blood were measured using

Table 1. Information list of patients before stem cell transplantation

\begin{tabular}{|c|c|c|c|c|c|c|c|}
\hline \multirow{2}{*}{ Case } & \multirow{2}{*}{ Age } & \multirow{2}{*}{ Breed } & \multirow{2}{*}{ Weight $(\mathrm{kg})$} & \multirow{2}{*}{ Symptom } & \multicolumn{3}{|c|}{ Hematologic levels associated CKD (mg/dL) } \\
\hline & & & & & BUN* & CREA** & PHOS*** \\
\hline 1 & 13 & Persian & 2.5 & Vomiting, diarrhea, anorexia, loss of vitality & 112 & 5.28 & 10.2 \\
\hline 2 & 13 & Korean shorthair & 4.1 & Vomiting, diarrhea, anorexia & 66.4 & 5.5 & 2.2 \\
\hline 3 & 8 & British shorthair & 4 & $\begin{array}{l}\text { Vomiting, diarrhea, abdominal pain, abdominal breathing, } \\
\text { subcutaneous edema, no appetite }\end{array}$ & 140 & 10.58 & 11.4 \\
\hline
\end{tabular}

\footnotetext{
*Reference range of BUN; $17.6-32.8 \mathrm{mg} / \mathrm{dL}$.

**Reference range of CREA; $0.8-1.8 \mathrm{mg} / \mathrm{dL}$.

***Reference range of PHOS; $2.6-6.0 \mathrm{mg} / \mathrm{dL}$.
}
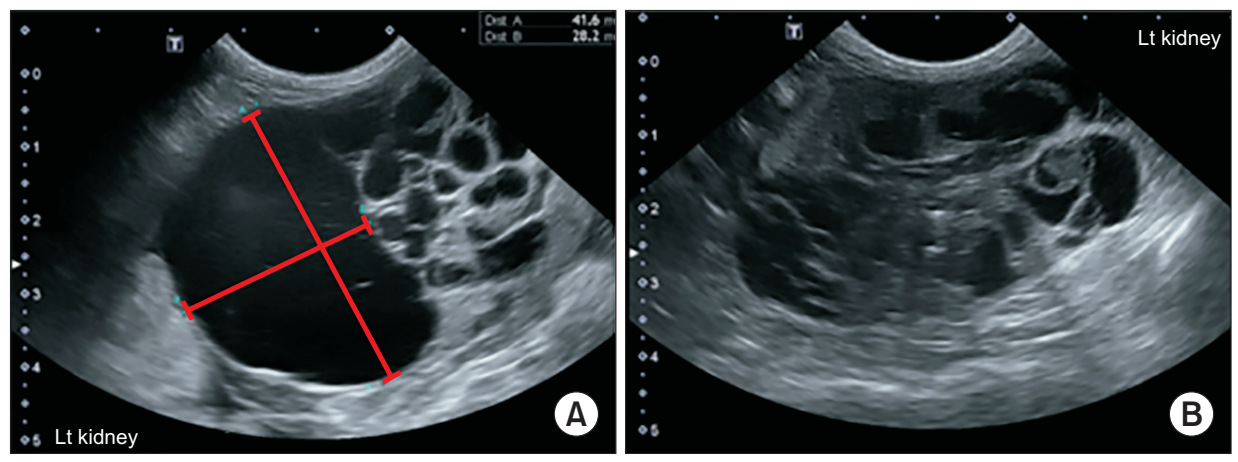

Fig. 1. Renal ultrasonographic findings in a cat (Case 1) with CKD. 
the 'DRI-CHEM 4000i' (Fujifilm, Japan) instrument and always QC test were performed before testing.

Mesenchymal stem cells from the cat's amniotic membrane were isolated by referring to the method of Vidane et al., 2014. Briefly, the cat placenta was washed in sterile PBS, the amniotic membrane was mechanically separated from the allantoic sac, and enzymatic digestion was performed using $0.1 \%$ collagenase solution to isolate amniotic-derived mesenchymal stem cells (Vidane et al., 2014).

All cats were premedicated with cefazolin $(25 \mathrm{mg} / \mathrm{kg}$ intravenously) and dexamethasone $(0.1 \mathrm{mg} / \mathrm{kg}$ intravenously). Allogeneic mesenchymal stem cells were infused intravenously for treating CKD. The number of allogenic stem cells was $1 \times 10^{6}$ cell $/ \mathrm{kg}$ and were mixed in normal saline with $200 \mathrm{IU}$ heparin sulfate and administered intravenously with a syringe pump-operating with $10 \mathrm{~mL} / \mathrm{kg} /$ $\mathrm{hr}$ injection speed. The dose was based on previous studies, and proved not to be associated, with adverse events as well (Quimby et al., 2013). The patient appeared clinically normal and stable during and after infusions.

Patients were treated with stem cell injection on Day 0, 7, and 14 or 30 through the same procedure. The cats had a
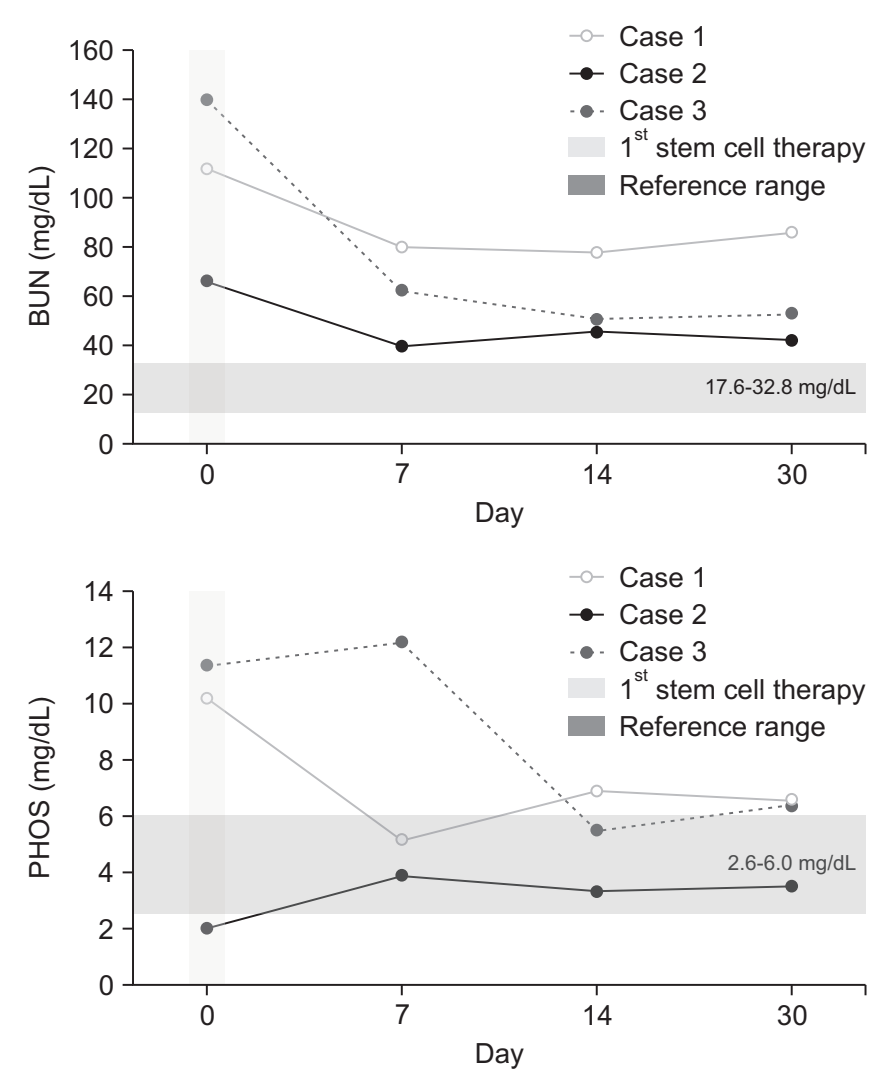

better appetite on Day 2 to 3 and good movement on Day 4 to 5 after injection, and no side effects like hypersensitivity were found during the three treatments. After three times of stem cell therapy, all patient's body conditions were much better than before the stem cell therapy.

BUN levels of each patient (Case 1, Case 2, and Case 3) were decreased to $80.3 \mathrm{mg} / \mathrm{dL}, 39.8 \mathrm{mg} / \mathrm{dL}$, and 62.7 $\mathrm{mg} / \mathrm{dL}$ after 1 week of fist stem cell transplantation and remained similar after the third stem cell treatment (Fig. 2A). CREA levels, after 1 week of first stem cell transplantation, significantly were decreased in each case to 5.3 $\mathrm{mg} / \mathrm{dL}, 2.4 \mathrm{mg} / \mathrm{dL}$, and $3.78 \mathrm{mg} / \mathrm{dL}$ (Fig. 2B). PHOS levels also were decreased to $12.2 \mathrm{mg} / \mathrm{dL}, 3.9 \mathrm{mg} / \mathrm{dL}, 5.1 \mathrm{mg} / \mathrm{dL}$ (Fig. 2C). Blood indexes related to CKD were within the normal range or a little bit higher than the normal range (Fig. 2). From the results of the hematologic analysis, it is thought that kidney function improved after the injection of stem cells. Also, the large anechoic structure seen in the left kidney in Case 1 was not seen on abdominal ultrasonography on day 30 after first stem cell transplantation. (Fig. 1B).

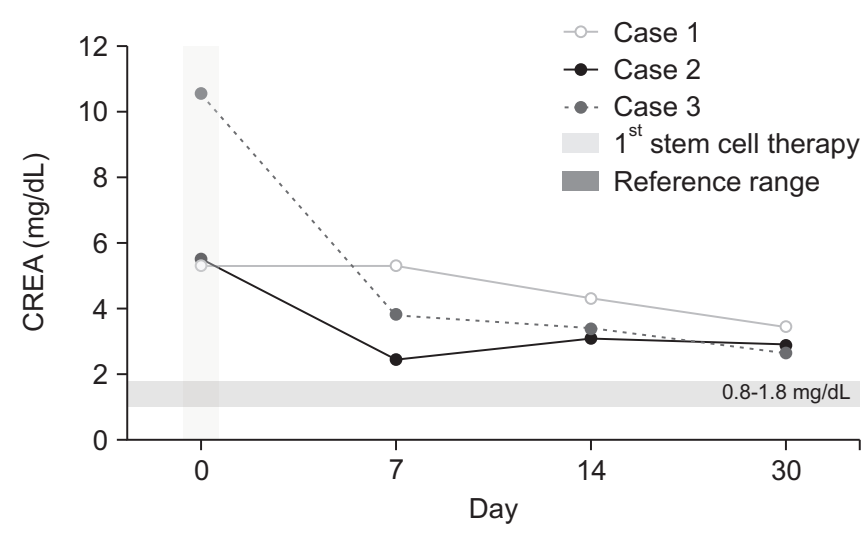

Fig. 2. Hematologic levels associated in 3 cats with CKD. 


\section{DISCUSSION}

CKD in cats has high morbidity and mortality, resulting in uremia and death. It can occur at all ages, but it is more frequent in old age. It is characterized that kidney damage has been continuously present for 3 months or longer. In CKD patients, renal function declines slowly over months or years. Although the loss of nephrons and secondary progressive impairment of renal function is irreversible, proper effective therapies for CKD can alleviate clinical signs and retard the progression of CKD (Finco et al., 1999). Conservative medical management, dietary therapy, fluid therapy, and renal replacement therapy are standard for CKD treatment (Polzin, 2017).

Recently, many studies have investigated the effectiveness of stem cells for treating kidney disease. The stem cell is mediated by multiple mechanisms, such as the secretion of cytokines and other molecules that inhibit inflammation and fibrosis and stimulating endogenous repair processes (Peired et al., 2016, Chung, 2019). Furthermore, previous studies have suggested the safety and efficacy of intravenous infusion of allogeneic stem cells (Quimby et al., 2013).

Here, intravenous injection of allogeneic stem cells was used for improving renal function, ultrasonographic findings, and symptoms. The expression levels of BUN and CREA were not within the normal reference range, clinical signs have improved remarkably as BUN and CREA levels decreased during stem cell therapy. The monitoring of serum BUN and CREA levels is known as clinically accurate and significant renal function assessment (Bellomo et al., 2004). This case report shows that allogeneic stem cell therapy didn't have any adverse effects on this study and provied several benefits to patients more than conservative medical treatment for CKD.

\section{CONCLUSION}

Stem cell therapy in cats with CKD could help to decrease azotemia and improve clinical signs. The potential application in CKD treatment with stem cell therapy can give helping maintain and improve healthy renal function and delaying the progression of tissue damage. Additionally, large-scale clinical trials with many patients are necessary to understand the effect of stem cell therapy in cats with CKD.

\section{CONFLICTS OF INTEREST}

No potential conflict of interest relevant to this article was reported.

\section{ACKNOWLEDGEMENTS}

This work has supported by the National Research Foundation of Korea (NRF) grant funded by the Korea government (MSIT) (2019M3A9H1103582).

\section{AUTHOR CONTRIBUTIONS}

Conceptualization: Seul Ah Noh and Junguk Ju

Data curation: Seul Ah Noh

Formal analysis: Seul Ah Noh and Junguk Ju

Funding acquisition: Junguk Ju

Investigation: Junguk Ju

Methodology: Junguk Ju

Project administration: Junguk Ju

Resources: Seul Ah Noh and Junguk Ju

Software: Seul Ah Noh and Taeho Kim

Supervision: Junguk Ju

Validation: Junguk Ju

Visualization: Seul Ah Noh and Taeho Kim

Writing - original draft: Seul Ah Noh and Taeho Kim

Writing - review \& editing: Junguk Ju and Taeho Kim

\section{AUTHOR'S POSITION AND ORCID NO.}

\author{
SA Noh, MS, \\ https://orcid.org/0000-0002-9335-0725 \\ T Kim, PhD, \\ https://orcid.org/0000-0002-1354-7019 \\ J Ju, MS, \\ https://orcid.org/0000-0002-9442-1548
}

\section{REFERENCES}

Bellomo R, Ronco C, Kellum JA, Mehta RL, Palevsky P. 2004. Acute renal failure - definition, outcome measures, animal models, fluid therapy and information technology needs: the Second International Consensus Conference of the Acute Dialysis Quality Initiative (ADQI) Group. Crit. Care 8:R204-R212.

Cetinkaya B, Unek G, Kipmen-Korgun D, Koksoy S, Korgun ET. 2019. Effects of human placental amnion derived mesenchy- 
mal stem cells on proliferation and apoptosis mechanisms in chronic kidney disease in the rat. Int. J. Stem Cells 12:151161.

Chan KW, Ping TY, Chou SJ, Zheng ZJ, Yang WC, Lai JM, Lo DY, Chang CC, Wu JT. 2014. Case report: treatment of an elderly dog with concurrent heart disease and acute uremia by hemodialysis. Taiwan Vet. J. 40:95-100.

Chung BH. 2019. Use of mesenchymal stem cells for chronic kidney disease. Kidney Res. Clin. Pract. 38:131-134.

De Coppi P, Bartsch G Jr, Siddiqui MM, Xu T, Santos CC, Perin L, Mostoslavsky G, Serre AC, Snyder EY, Yoo JJ, Furth ME, Soker S, Atala A. 2007. Isolation of amniotic stem cell lines with potential for therapy. Nat. Biotechnol. 25:100-106.

Filioli Uranio M, Valentini L, Lange-Consiglio A, Caira M, Guaricci AC, L'Abbate A, Catacchio CR, Ventura M, Cremonesi F, Dell'Aquila ME. 2011. Isolation, proliferation, cytogenetic, and molecular characterization and in vitro differentiation potency of canine stem cells from foetal adnexa: a comparative study of amniotic fluid, amnion, and umbilical cord matrix. Mol. Reprod. Dev. 78:361-373.

Finco DR, Brown SA, Brown CA, Crowell WA, Cooper TA, Barsanti JA. 1999. Progression of chronic renal disease in the dog. J. Vet. Intern. Med. 13:516-528.

Jo JH, Kim KH, Kim TM. 2019. The potential of renal progenitor cells in kidney diseases: preclinical findings. J. Anim. Reprod. Biotechnol. 34:70-74.

Lee HJ, Jeon RH, Park BJ, Jang SJ, Lee SL, Rho GJ, Kim SJ, Lee WJ. 2019a. Differentiation inductions altered telomere length and telomerase activity in human dental pulpderived mesenchymal stem cell. J. Anim. Reprod. Biotechnol. 34:9399.

Lee HJ, Park BJ, Jeon RH, Jang SJ, Son YB, Lee SL, Rho GJ, Kim SJ, Lee WJ. 2019b. Alteration of apoptosis during differentiation in human dental pulp-derived mesenchymal stem cell.
J Anim. Reprod. Biotechnol. 34:2-9.

Mahiddine FY, Qamar AY, Kim MJ. 2020. Canine amniotic membrane derived mesenchymal stem cells exosomes addition in canine sperm freezing medium. J Anim. Reprod. Biotechnol. 35:268-272.

Moon SW, Lee HJ, Lee WJ, Ock SA, Lee SL. 2018. Trans-differentiation induction of human-mesenchymal stem cells derived from different tissue origin and evaluation of their potential for differentiation into corneal epithelial-like cells. J. Emb. Trans. 33:85-97.

Peired AJ, Sisti A, Romagnani P. 2016. Mesenchymal stem cellbased therapy for kidney disease: a review of clinical evidence. Stem Cells Int. 2016:4798639.

Polzin DJ. 2017. Chronic kidney disease. In: Ettinger SJ, Feldman EC, Cote E (Eds.), Textbook of Veterinary Internal Medicine. 8th ed, Elsevier, St. Louis, pp. 1938-1958.

Quimby JM, Webb TL, Gibbons DS, Dow SW. 2011. Evaluation of intrarenal mesenchymal stem cell injection for treatment of chronic kidney disease in cats: a pilot study. J. Feline Med. Surg. 13:418-426.

Quimby JM, Webb TL, Habenicht LM, Dow SW. 2013. Safety and efficacy of intravenous infusion of allogeneic cryopreserved mesenchymal stem cells for treatment of chronic kidney disease in cats: results of three sequential pilot studies. Stem Cell Res. Ther. 4:48.

Vidane AS, Souza AF, Sampaio RV, Bressan FF, Pieri NC, Martins DS, Meirelles FV, Miglino MA, Ambrósio CE. 2014. Cat amniotic membrane multipotent cells are nontumorigenic and are safe for use in cell transplantation. Stem Cells Cloning 7:71-78.

Webb TL, Quimby JM, Dow SW. 2012. In vitro comparison of feline bone marrow-derived and adipose tissue-derived mesenchymal stem cells. J. Feline Med. Surg. 14:165-168. 